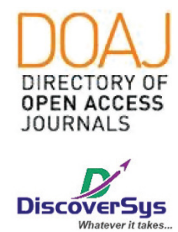

Published by DiscoverSys

\section{Gagal atrium kiri: terminologi yang perlu diketahui}

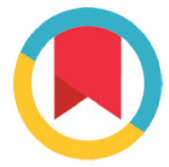

CrossMark

\author{
Sidhi Laksono Purwowiyoto ${ }^{1,2^{*}}$, Budhi Setianto ${ }^{3}$, I Nyoman Wiryawan ${ }^{4}$, Steven Philip Surya ${ }^{5}$
}

\title{
ABSTRACT
}

Heart failure is the terminal stage of all the heart pathological conditions. The common understanding in heart failure is always preceded by left ventricular dysfunction. There are several clinical studies that indicate heart failure might occur without prior left ventricular dysfunction. Left atrial dysfunction may have more important roles than we previously thought in the context of heart failure. The atrium has a unique and different anatomical structure and function compared to the ventricles. Left atrial failure can occur independently of left ventricular dysfunction or mitral valve abnormalities. Atrial failure, similar to ventricular failure, could also cause or initiate global heart failure. The mechanism of atrial failure can be caused by fibrosis, electrical and mechanical dysfunction. Through this article, we would emphasize that atrial failure also has clinical significance and may explain heart failure with the condition of the sustained ejection fraction.

Keywords: atrium, anatomic structure, function, mechanism, atrial failure

Cite This Article: Laksono, S., Setianto, B., Wiryawan, I.N., Surya, S.P. 2020. Gagal atrium kiri: terminologi yang perlu diketahui. Intisari Sains Medis 11 (3): 1034-1038. D0I: 10.15562/ism.v11i3.761

${ }^{1}$ Kepala Laboratorium Kateterisasi Jantung, SMF Jantung FK UHAMKA/RSUD Pasar Rebo, Jakarta Timur

2Fakultas Kedokteran, Universitas Muhammadiyah Prof. DR. Hamka, Tangerang

${ }^{3}$ Departemen Kardiologi dan Kedokteran Vaskuler, Pusat Jantung Nasional Harapan Kita, Fakultas Kedokteran Universitas Indonesia

${ }^{4}$ Departemen Kardiologi dan Kedokteran Vaskuler, RSUP Sanglah, Fakultas Kedokteran Universitas Udayana

${ }^{5}$ RS Angkatan Darat Kesdam Jaya Cijantung, Jakarta

*Korespondensi: Sidhi Laksono Purwowiyoto ; Fakultas Kedokteran UHAMKA, Tangerang, Indonesia. sidhilaksono@uhamka.ac.id

Diterima: 29-05-2020

Disetujui: 03-10-2020

Diterbitkan: 06-11-2020

\section{ABSTRAK}

Gagal jantung adalah hasil akhir dari semua kondisi patologi di jantung. Terminologi umum dalam gagal jantung selalu didahului oleh disfungsi ventrikel kiri. Ada beberapa studi klinis yang menunjukkan gagal jantung mungkin terjadi tanpa disfungsi ventrikel kiri sebelumnya. Disfungsi atrium kiri mungkin memiliki peran penting lebih dari pada yang kita pikirkan sebelumnya pada kondisi gagal jantung. Berbeda dengan ventrikel, atrium memiliki struktur anatomis dan fungsi yang unik dan berbeda. Gagal

atrium kiri dapat terjadi secara independen terhadap disfungsi ventrikel kiri dan kelainan katup mitral. Seperti halnya ventrikel kiri, gagal atrium dapat menyebabkan gagal jantung secara global. Mekanisme gagal ventrikel dapat disebabkan darifibrosis, disfungsi elektrik dan mekanik. Melalui artikel ini, kami akan menjelaskan bahwa kegagalan fungsi atrium juga memiliki signifikansi klinis dan mungkin menjelaskan gagal jantung dengan kondisi fraksi ejeksi yang dipertahankan.

Kata kunci: atrium, struktur anatomi, fungsi, mekanisme, gagal atrium

Sitasi Artikel ini: Laksono, S., Setianto, B., Wiryawan, I.N., Surya, S.P. 2020. Gagal atrium kiri: terminologi yang perlu diketahui. Intisari Sains Medis 11 (3): 1034-1038. D0l: 10.15562/ism.v11i3.761

\section{PENDAHULUAN}

Gagal jantung menjadi kisah yang tidak ada habisnya untuk dibahas di dunia kedokteran. Meskipun telah banyak upaya untuk menjawab kompleksitas dari gagal jantung, tidak ada paradigma konseptual tunggal yang dapat merasionalisasi peristiwa yang sebenarnya. Sindrom gagal jantung didefinisikan sebagai ketidakmampuan jantung untuk menyediakan darah yang cukup untuk kebutuhan tubuh dan diklasifikasikan berdasarkan sistolik dan/atau diastolik, akut atau kronis, kompensasi atau tidak terkompensasi, serta keterlibatan satu atau dua ventrikel. ${ }^{1}$ Banyak pendapat yang mempertimbangkan faktor neurohormonal dan peran ventrikel sebagai masalah utama dalam mekanisme patologi gagal jantung sedangkan peran atrium kurang mendapat perhatian. ${ }^{2}$ Gagal jantung dimulai ketika kerusakan miosit jantung atau perubahan miokardium dalam menghasilkan kekuatan kontraksi. Akibatnya, jantung tidak bisa berkontraksi dan memompa darah secara normal. Sampai saat ini, melalui pengembangan modalitas pencitraan jantung, banyak ahli telah sepakat bahwa atrium memiliki peran lebih penting dari yang diperkirakan sebelumnya. Perubahan fungsi 
atrium muncul dari perubahan mekanisnya, fungsi hemostatik, atau fisiologi listrik ke ventrikel. ${ }^{3}$

Gagal jantung memiliki beragam gejala klinis. Meskipun dengan adanya disfungsi ventrikel kiri (VKi), kondisi asimptomatik dapat terjadi dan tidak ada penjelasan baku yang dapat menjelaskan fenomena tersebut. ${ }^{2}$ Namun, banyak pendapat yang menyatakan bahwa faktor neurohormonal dan sitokin menyebabkan perubahan jantung, termasuk ruang atrium..$^{2,3}$ Atrium kiri (AKi), tidak hanya terlibat dalam pengisian $\mathrm{VKi}$, tetapi memiliki peran yang lebih besar melalui berbagai mekanisme seperti fungsi endokrin (sekresi peptida natriuretik atrium atau PNA) dan fungsi regulator (pengaturan sistem saraf otonom dan hormon antidiuretik-ADH). ${ }^{4}$ Saat ini timbul gagasan untuk mempertimbangkan gagal atrium sebagai entitas baru yang secara terpisah dapat melemahkan fungsi jantung tanpa kelainan katup atau ventrikel yang signifikan. ${ }^{3} \mathrm{Hal}$ ini didasarkan pada temuan bahwa gagal AKi dapat memicu aktivitas neurohumoral dan vasokonstriksi yang berlebihan serta keadaan volume cairan yang berlebih. ${ }^{5}$

\section{STRUKTUR DAN FUNGSI ATRIUM KIRI}

McAlpine mengklasifikasikan otot dinding AKi menjadi superior, posterior, lateral kiri, septal atau medial, dan anterior terutama untuk kebutuhan intervensi pada jantung. ${ }^{6}$ Namun demikian, ketebalan dinding otot AKi bervariasi, dan terutama bagian anterior sangat tipis di dekat ruang depan annulus mitral dan didefinisikan sebagai area "tidak terlindungi" oleh McAlpine yang memiliki risiko perforasi yang lebih besar. ${ }^{6,7}$ Pada bagian posterior, area di sekitar lubang vena paru kiri dan kanan cenderung lebih tipis dan juga berbatasan dengan saraf vagal. ${ }^{6}$ Muscle sleeve yang menyebar di AKi ke aspek luar dari dinding vena dianggap penting dalam aktivitas elektrikal jantung, terutama yang berhubungan dengan aktivitas fokal yang mengawali fibrilasi atrium (FA). ${ }^{8}$ Bantalan lemak epikardial pada struktur persimpangan veno-atrium mengandung ikatan saraf otonom dan ganglion intrinsik. ${ }^{6}$

Anatomi vena pulmonalis (VP) memiliki anastomosis bervariasi ke AKi yang ditemukan pada aspek posterior AKi. ${ }^{9}$ Pada persimpangan veno-atrium, tidak ada struktur pemisah yang jelas antara atrium dan vena. Otot-otot atrium meluas ke VP dan bertindak sebagai sfingter yang mencegah refluks selama sistol atrium. Bagian Ini dikaitkan dengan sumber denyut ektopik. ${ }^{8}$ Selain itu, struktur VP juga mendukung pengisian VKi diastolik awal dan menghindari stasis darah. Pada dinding AKi terdapat seperti lipatan yang menonjol ke eksternal yang dikenal sebagai left atrium appendage (LAA).
Struktur ini memiliki ukuran kecil, sempit, dan bentuk tabung, serta lebih kecil dibandingkan right atrium appendage (RAA). ${ }^{6}$ Sebuah studi postmortem menunjukkan atrium appendage (AA) dari pasien dengan yang memiliki fibrilasi atrium, volumenya tiga kali lebih besar dibanding dengan populasi dengan detak jantung normal. ${ }^{11}$ Beberapa penelitian juga menyimpulkan LAA terkait dengan fibrilasi atrium dan pembentukan trombus. ${ }^{11,12}$

Secara mekanis AKi memiliki tiga fase yakni fase pengisian, fase pengosongan pasif dan fase pengosongan aktif. ${ }^{3,13} \mathrm{AKi}$ akan diregangkan selama fase pengisian dan darah akan mengalir dari VP ke AKi. Fase pengisian diikuti oleh pengosongan pasif, yang ditandai dengan pembukaan katup mitral dan darah akan secara pasif mengalir dari atrium ke ventrikel. Segera setelah itu, otot di AKi akan memendek (pengosongan aktif) untuk memastikan semua volume di dalam AKi ditransfer ke ruang ventrikel, disebut sebagai sistolik atrium atau pompa dorong AKi. Fungsi sistolik AKi dipengaruhi oleh panjang miokardium saat diastolik, afterload dan kontraktilitas miokard. ${ }^{14}$

\section{GAGAL ATRIUM KIRI}

Studi terbaru menunjukkan disfungsi Aki dapat terjadi tanpa didahului disfungsi VKi sebelumnya dan/atau kelainan katup mitral., ${ }^{3,15-17}$ Bisbal, et al. menyarankan definisi untuk gagal atrium sebagai kelainan fungsi (anatomi, mekanik, listrik, dan/ atau reologis, termasuk stasis darah) yang dapat mengubah kinerja jantung dan gejala jantung, dan kualitas hidup atau harapan hidup yang memburuk, tanpa adanya abnormalitas katup atau ventrikel yang signifikan. ${ }^{3}$ Selain itu, penelitian lain mendefinisikan disfungsi AKi sebagai kecepatan puncak pengosongan AA $<40 \mathrm{~cm} /$ detik, atau adanya kontras gema spontan, dan/atau trombus di AKi atau LAA ditemukan dengan ekokardiografi transesofageal (ETE). ${ }^{16}$

Beberapa titik anatomi pada atrium dapat memulai ritme mereka sendiri (ektopik), ${ }^{8,11}$ Masalah konduksi listrik pada atrium seperti fibrilasi atrium (FA) adalah salah satu masalah ritme yang cukup sering ditemui bagi ahli jantung. Akibatnya pompa AKi dapat berubah dan dilatasi ruang AKi serta dapat berakhir dengan gagal AKi. ${ }^{5}$ Sebuah studi kohort menemukan korelasi disfungsi AKi pada pasien FA walaupun telah pulih selama 3 bulan (sinus ritme). ${ }^{16}$ Perubahan fungsi AKi pada pasien irama sinus yang sebelumnya didiagnosis dengan kondisi FA mungkin terjadi karena remodeling mekanik dan neurohormonal yang menyebabkan gagal atrium. ${ }^{16,18}$ Selain itu, subpopulasi yang menerima berbagai jenis obat yang berbeda (penyekat beta, inhibitor enzim 
pengkonversi angiotensin atau $\mathrm{ACEi}$, penyekat reseptor angiotensin atau $\mathrm{ARB}$, obat antiaritmia, digitalis, diuretik, dan penyekat kanal kalsium atau CCB), kejadian disfungsi AKi tidak berbeda secara signifikan. Ruang dimensi AKi secara signifikan lebih besar pada pasien dengan disfungsi AKi dibandingkan dengan kelompok kontrol (40 \pm $6 \mathrm{~mm}$ vs $36 \pm 8 \mathrm{~mm}, \mathrm{p}=0,018) .{ }^{16}$ Studi investigasi FA menyimpulkan beberapa faktor risiko klinis yang secara independen terkait dengan disfungsi VKi seperti usia lebih dari 65 tahun, riwayat hipertensi, diabetes melitus, penyakit arteri koroner (CAD), dan transient ischemic stroke (TIA) atau stroke sebelumnya. ${ }^{19}$ Selain FA, distorsi pada sistem konduksi atrioventrikular (AV) dan disinkronisasi atrium juga dapat memicu gagal atrium. ${ }^{3}$

Kardiomiopati atrium yang disebabkan oleh patologi atrium primer atau sekunder yang terisolasi juga dapat menyebabkan gagal atrium. ${ }^{3,6}$ Dalam konsensus baru-baru ini, kardiomiopati digambarkan sebagai setiap kompleks perubahan struktural, arsitektur, kontraktil, atau elektrofisiologis yang mempengaruhi atrium dengan potensi untuk menghasilkan manifestasi yang relevan secara klinis. ${ }^{20}$ Etiologi terisolasi kardiomiopati atrium selain FA adalah genetik (amiloidosis), infektif (miokarditis), penyebab infiltratif, inflamasi, dan toksin. ${ }^{21}$ Penyebab spesifik apa pun yang memengaruhi ruang atrium akan menyebabkan takiaritmia dan berakhir dengan gangguan kontraksi sistolik atrium dan dilatasi atrium lebih lanjut bahkan setelah irama jantung kembali normal lagi. ${ }^{22}$ Kardiomiopati atrium dapat berkembang menjadi fibrosis atrium, disfungsi listrik, atau keadaan prokoagulan yang memperburuk kondisi atrium..$^{20,23}$ (Gambar 1)

Mekanisme ketiga gagal atrium melalui remodeling atrium. ${ }^{3}$ Remodeling atrium kiri terdiri dari spektrum perubahan struktural dan

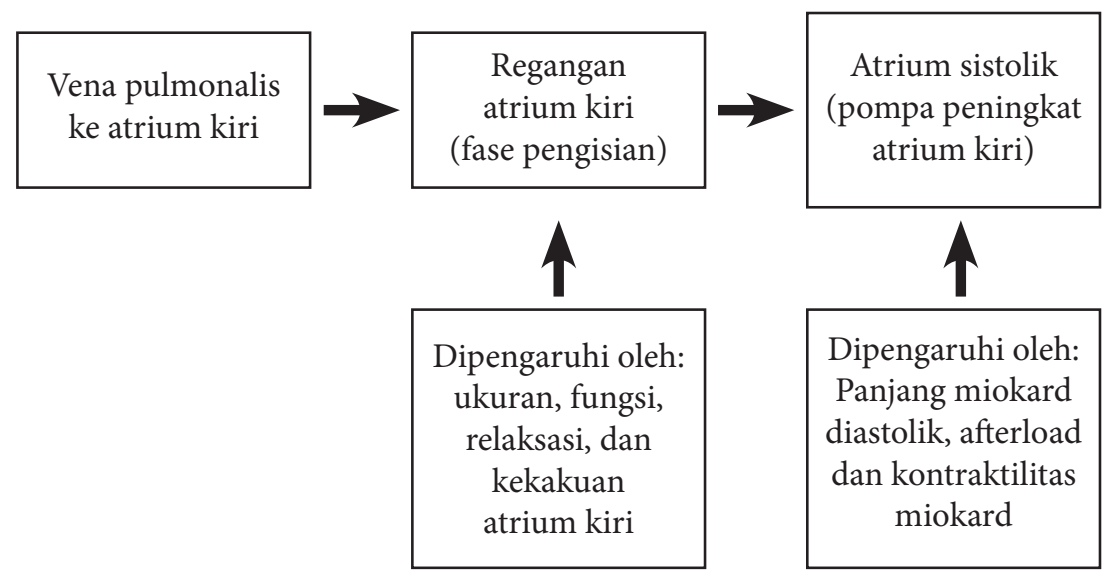

kelistrikan yang mengarah pada dilatasi atrium dan mengganggu fungsi atrium. ${ }^{6}$ Masalah remodeling atrium, walaupun tidak secara eksklusif, disebabkan oleh volume/tekanan yang berlebihan. Faktor klinis lain yang mempengaruhi remodeling adalah obesitas, olahraga, apnea tidur obstruktif, dan aterosklerosis. ${ }^{24}$ Respon maladaptif sel atrium dalam kondisi stres tinggi (seperti volume/tekanan berlebih) adalah pertumbuhan miosit abnormal, hipertrofi, nekrosis, apoptosis, perubahan matriks ekstraseluler (extracellular matrix/ECM), kalibrasi ulang produksi energi, perubahan ekspresi saluran ionik seluler dan hormon atrium. ${ }^{6,25}$ Respon maladaptif menghasilkan fibrosis atrium dan itu dapat menyebabkan pemendekan dari refraksi atrium, re-enterant wavelength, dan menciptakan heterogenitas konduksi lokal (aritmia). ${ }^{26}$ Hubungan antara aritmia listrik dan remodeling jantung masih kurang dipahami, tetapi kompleksitas patogenesis mungkin melibatkan beberapa agen patogenesis seperti stres oksidatif, kelebihan kalsium, dilatasi atrium, mikro-RNA, peradangan, dan aktivasi myofibroblast. Perubahan - perubahan tersebut adalah mekanisme yang mendasari untuk remodeling atrium. ${ }^{27}$

\section{MEKANISME PERBURUKAN PADA GAGAL ATRIUM}

Setelah melalui beberapa etiologi dan patofisiologi sepert penjelasan sebelumnya, fungsi AKi akhirnya gagal (Tabel 1). Bantalan lemak di sekitar ostium VP yang terdiri dari pleksus gangglion (GP) dan dipersarafi dengan kedua saraf adrenergik dan saraf vagal. ${ }^{28}$ Terdapat reflex dari reseptor volume yang diaktifkan secara mekanis di persimpangan vena-atrium paru. Peningkatan volume darah yang berlebihan akan menyebabkan penghambatan aktivitas saraf simpatis ginjal, meningkatkan diuresis, dan memengaruhi detak jantung (refleks Bainbridge dan reverse Bainbridge). ${ }^{29} \mathrm{Di}$ sisi lain, kurangnya volume darah akan menyebabkan kehausan dan pelepasan hormon vasopresin. ${ }^{30}$ Gagal AKi menurunkan regulasi inhibisi simpatis dan meningkatkan regulasi eksitasi simpatis. ${ }^{6}$ Studi terbaru berhasil menemukan korelasi antara aktivasi berlebihan simpatis dengan kapasitas fungsional New York Heart Association (NYHA) dan prognosis pasien gagal jantung. ${ }^{31}$ Akibatnya, perubahan regulasi simpatik pada gagal AKi dapat memperburuk kondisi atrium dan akhirnya jantung secara keseluruhan. 
Tabel 1. Penyebab dan pencetus gagal atrium

A. Disinkroni elektrikal

- Disinkroni Atrioventrikuler

- Disinkroni Atriuml

B. Disfungsi pompa peningkat dan pengisian

- Aktivasi atrium yang cepat/ tidak teratur

- Atrium fibrosis yang luas

C. Fungsi conduit yang terganggu

Tipe peptida natriuretik (natriuretic peptide / NP) terdiri dari tipe atrium, tipe otak, dan tipe c dengan reseptornya masing - masing. Natriuretic peptide tipe atrium (atrium natriuretic peptide/ $A N P$ ) disimpan di dalam atrium dan myocyte pelengkap dan dilepaskan selama gangguan pada dinding AKi. ${ }^{31}$ Prekursor ANP adalah proANP dengan 126 asam amino yang disimpan dalam granula sekretor kardiomiosit atrium. ProANP yang dikeluarkan dari atrium memiliki 3 bentuk utama, proANP dengan 126 asam amino, proANP dengan 98 asam amino N terminal peptida (NT-proANP), dan pro ANP dengan 28 asam amino terminal C (ANP) yang aktif secara hormonal. ${ }^{33}$ ANP memiliki peranan penting dalam mekanisme kardioprotektif melalui beberapa mekanisme. ${ }^{34,35}$ Namun, ketika gagal AKi terjadi, pembentukan ANP akan cacat dan juga tidak sensitif. ${ }^{6}$

\section{RELEVANSI KLINIS GAGAL ATRIUM}

Gagal AKi akan membawa beberapa konsekuensi klinis seperti pengisian VKi yang suboptimal, FA yang dihasilkan dari gagal atrium dan berkembang menjadi hipertensi paru, gagal jantung secara keseluruhan (global heart failure), dan meningkatkan trombogenitas. ${ }^{3}$ Calenda, et al. menunjukkan miopati atrium dapat memulai substrat atrium yang menyebabkan peningkatan trombogenitas. $^{36}$ Selain itu, studi populasi MESA juga memiliki kesimpulan yang sama. ${ }^{37}$ Sejumlah penelitian juga menunjukkan korelasi antara remodeling atrium dan miopati dengan peningkatan risiko stroke. ${ }^{38,39}$ Perubahan aktivasi simpatik mengakibatkan disfungsi endotel AKi dan fibrosis, perubahan tersebut terkait dengan meningkatnya kejadian stroke. ${ }^{40}$

\section{SIMPULAN}

Sejak dulu ahli jantung percaya gagal AKi sebagai konsekuensi dari disfungsi VKi. Namun studi terbaru telah membuka kemungkinan baru, AKi sebagai sumber entitas baru kejadian gagal jantung. Gagal AKi didefinisikan sebagai kegagalan Aki yang terisolasi atau tanpa abnormalitas VKi dan katup mitral sebelumnya. Terdapat beberapa etiologi gagal
Aki yang akan memicu kondisi perburukan jantung pada pasien gagal jantung terlepas dari keterlibatan VKi. Gagal AKi juga memiliki signifikansi klinis.

\section{KONFLIK KEPENTINGAN}

Tidak terdapat konflik kepentingan dalam penulisan artikel ini.

\section{PENDANAAN}

Artikel ini tidak mendapat dana dari sponsor atau pihak ketiga.

\section{KONTRIBUSI PENULIS}

Masing-masing penulis memiliki kontribusi yang setara dalam penulisan artikel ini.

\section{DAFTAR PUSTAKA}

1. Kirali K, Ozer T, Ozgur MM. Pathophysiology in heart failure. In: Kirali K, editor. Cardiomyopaties: type and treatment. Crotia: InTech:2017. P.17-38.

2. Hasenfuss G, Mann DL. Pathophysiology of heart failure. In: Mann DL, Zipes DP, Libby P, Bonow RO, editor. Braunwald's heart disease: a textbook of cardiovascular medicine, $10^{\text {th }}$ ed. Philadelphia: ElsevierInc:2015. P.454-72.

3. Bisbal F, Baranchuk A, Braunwald E, de Luna AB, BayesGenis A. Atriuml failure as a clinical entity: jacc review topic of the week. J Am Coll Cardiol. 2020;75:222-32.

4. Rossi A, GheorghiadeM, Triposkiadis F, Solomon SD, Pieske B, Buttler J. Left atrium in heart failure with preserved ejection fraction: structure, function, and significance. Circ Heart Fail. 2014;7(6):1042-9.

5. Triposkiadis F, Pieske B, Butler J, Parissis J, Giamouzis G, Skoularigis J, et al. Global left atriuml failure in heart failure. Eur J Heart Fail.2016;18:1307-20.

6. Ho SY, Cabrera JA, Sanchez-Quintana D. Left atriuml anatomy revisited. Circ Arrhytm Electrophysiol. 2012;5:220-8

7. Sanchez-Quintana D, Cabrera JA, Climent V, Farre J, Mendonca MC, Ho SY. Anatomic relations between the esophagus and left atrium and relevance for ablation of atriuml fibrillation. Circulation. 2005;112(10):1400-5.

8. Whiteman S, Saker E, Courant V, Salandy S, Gielecki J, Zurada A, et al. An anatomical review of the left atrium. Transl Res Anat. 2019;17:100052.

9. Ho S, Cabrera J, Tran V, Farre J, Anderson R, SanchezQuintana D. Architecture of the pulmonary veins: relevance to radiofrequency ablation. Heart. 2001:86(3):265-70.

10. Kilner PJ, Yang GZ, Wilkes AJ, Mohiaddin RH, Firmin DN, Yacoub MH. Asymmetric redirection of flow through the heart. Nature. 2000;13;404(6779):759-61.

11. Syed FF, Noheria A, DeSimone CV, Asirvatham SJ. Left atriuml appendafe ligation and exclusion technology in the incubator. J Atr Fibrillation. 2015;8(2):1160.

12. Yamamoto M, Seo Y, Kawamtsu N, Sato K, Sugano A, Machino-Ohtsuka T, et al. Complex left atriuml appendage morphology and left atriuml appendage thrombus formation in patients with atriuml fibrillation. Circ Cardiovasc Imaging. 2014;7(2):337-43.

13. Karayannis G, Kitsios G, Kotidis H, Triposkiadis F. Left atriuml remodeling contributes to the progression of asymptomatic left ventricular systolic dysfunction 
to chronic symptomatic heart failure. Heart Fail Rev. 2008;13(1):91-8.

14. Seward JB, Hebl VB. Left atriuml anatomy and physiology: echo/doppler assessment. Curr Opin Cardiol. 2014;29(5): 403-7.

15. Mateescu AD, Calin A, Beladan CC, Rosca M, Enache R, Bailcus $\mathrm{C}$, et al. Left atriuml dysfunction as an independent correlate of heart failure symptoms in patients with severe aortic stenosis and preserved left ventricula ejection fraction. J Am Soc Echocardiogr. 2019;32(2):257-66.

16. Wang YC, Lin JL, Hwang JJ, Lin MS, Tseng CD, Huang SKS, et al. Left atriuml dysfunction in patient with atriuml fibrillation after successful rhythm control for $>3$ months. Chest. 2005; 128(4):2551-6.

17. Wang $\mathrm{D}, \mathrm{Xu} \mathrm{JZ}$, Chen $\mathrm{X}, \mathrm{Xu}$ TY, Zhang W, Li Y, et al. Left atriuml myocardial dysfunction in patients with primary aldosteronism as assessed by speckle-tracking echocardiography. J Hypertens. 2019;37(10):2032-40.

18. Wozakowska-Kaplon B, Opolski G. Concomitant recovery of atriuml mechanical and endocrine function after cardioversion in patient with persistent atriuml fibrillation.

19. Siontis KC, Geske JB, Gersh BJ. Atriuml fibrillation pathophysiology and prognosis: insight from cardiovascular imaging. Circ Cardiovasc Imaging. 2015;8(6):e003020.

20. Goette A, Kalman JM, Aguinaga L, Akar J, Cabrera JA, Chen SA, et al. EHRA/HRS/APHRS/SOLAECE expert consensus on trial cardiomyopathies: definition, characterization, and clinical implication. Heart Rhythym. 2017;14(1):e3-e40.

21. Agarwal R. Atriuml cardiomyopathy: a new and novel concept. J Pract Cardiovasc Sci. 2019;5:64-5.

22. Fatkin D, Nikolova-Krstevski VN. Atriuml cardiomyopathy an orphan disease or common disorder? Circ Cardiovasc Genet. 2013;6:6-5.

23. Dan GA. Rhythm control in AF: have we reached the last frontier? European Cardiology Review. 2019;14(2):77-81.

24. Miller JD, Aronis KN, Chrispin J, Patil KD, Marine JE, Martin SS, et al. Obesity, exercise, obstructive sleep apnea, and modifiable atherosclerotic cardiovascular disease risk factors in atriuml fibrillation. J Am Coll Cardiol. 2015;66(25):2899-906.

25. Selvetella G, Hirsch E, Notte A, Tarone G, Lembo G. Adaptive and maladaptive hypertrophic pathway: points of convergence and divergence. Cardiovasc Res.2004;63(3):373-80.

26. Jalife J, Kaur K. Atriuml remodeling fibrosis, and atriuml fibrillation. Trends Cardiovasc Med. 2014;25(6):475-84.

27. Pinho-Gomes AC, Reilly S, Brandes RP, Casadei B. Targeting inflammation and oxidative stress in atriuml fibrillation: role of 3-hydroxyl-3methylglutaryl-coenzyme a reductase inhibition with statins. Antioxid Redox Signal. 2014;20(8):1268-85.
28. Hou Y, Scherlag BJ, Lin J, Zhang Y, Lu Z, Truong K, et al. Ganglionated plexi modulate extrinsic cardiac autonomic nerve input: effects on sinus rate, atrioventricular conduction, refractoriness, and inducibility of atriuml fibrillation. J Am Coll Cardiol. 2007;50(1):61-8.

29. Arrigo M, Huber LC. Eponyms in cardiopulmonary reflexes. Am J Cardiol. 2013;112(3):449-53.

30. Bichet DG. Central vasopressin: dendritic and axonal secretion and renal actions. Clin Kidney J. 2014;7(3): 242-7.

31. Zhang DY, Anderson AS. The sympathetic nervous system and heart failure. Cardiol Clin. 2014;32(1):33-vii.

32. Januzzi JL. Natriuretic peptide as biomarkers in heart failure. J investing Med. 2013;61(6)950-5.

33. Mair J, Lindahl B, Giannitsis E, Huber K, Thygesen K, Plebani $M$, et al. Will sacubitril-valsartan diminish the clinical utility of b-type natriuretic peptide testing in acute cardiac care? Eur Heart J Acute Cardiovasc Care. 2017;6(4):321-8.

34. Nishikimi T, Kuwahara K, Nakao K. Current biochemistry, molecular biology, and clinical relevance of natriuretic peptides. J Cardiol. 2011;57(2):131-40.

35. Brutsaert DL. Cardiac endothelial-myocardial signaling: its role in cardiac growth, contractile performance, and rhythmicity. Physiol Rev. 2003;83(1):59-115.

36. Calenda BW, Fuster V, Halperin JL, Granger CB. Stroke risk assessment in atriuml fibrillation: risk factor and markers of atriuml myopathy. Nat Rev Cardiol. 13(9):549-59.

37. Habibi M, Zareian M, Ambale Venkatesh B, Samiei S, Imai $\mathrm{M}, \mathrm{Wu} \mathrm{C}$, et al. Left atriuml mechanical function and incident ischemic cerebrovascular event independent of AF: insight from the MESA study. JACC Cardiovasc Imaging. 2019;12(12):2417-27.

38. Kuppahally SS, Akoum N, Burgon NS, Badger TJ, Kholmovski EG, Vijayakumar S, et al. Left atriuml strain and strain rate in patient with paroxysmal and persistent atriuml fibrillation: relationship to left atriuml structural remodeling detected by delayed-enhancement MRI. Circ Cardiovasc Imaging. 2010;3(3):231-9.

39. Fonseca AC, Alves P, Inacio N, Marto JP, Viana-Baptista M, Pinho-E-Melo T, et al. Patients with undetermined stroke have increased atriuml fibrosis: a cardiac magnetic resonance imaging study. Stroke. 2018;49(3):734-7.

40. Balint B, Jaremek V, Thorburn V, Whitehead SN, Sposato LA. Left atriuml microvascular endothelial dysfunction, myocardial inflammation and fibrosis after selective insular cortex ischemic stroke. Int J Cardiol. 2019;292:148-55.

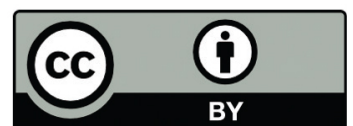

This work is licensed under a Creative Commons Attribution 